\title{
Short-Term Variability of Nutrients and Fecal Indicator Bacteria within the Gold Coast Seaway, Southern Moreton Bay (Australia)
}

\author{
R.J.K. Dunn ${ }^{\dagger *}$, K. Catterall ${ }^{\ddagger}$, A. Hollingsworth ${ }^{\ddagger}$, S. Kirkpatrick ${ }^{\S}$, G. Capati ${ }^{\ddagger}$, S. Hudson ${ }^{\dagger * *}$, \\ S. Khan , J.G. Panther ${ }^{\dagger * *}$, G. Stuart ${ }^{\S \dagger \dagger}$, S. Szylkarski ${ }^{\dagger \dagger}$, P.R. Teasdale ${ }^{\dagger * *}$, \\ R.B. Tomlinson ${ }^{\S * * *}$, and D.T. Welsh ${ }^{\dagger * *}$
}

${ }^{\dagger}$ Australian Rivers Institute and Griffith School of

Environment

Griffith University

Gold Coast Campus, QLD 4222,

Australia
Gold Coast Water

PO Box 5042

Gold Coast Mail Centre, QLD

9729, Australia

\author{
${ }^{\S}$ Griffith Centre for Coastal \\ Management \\ Griffith University \\ Gold Coast Campus, QLD 4222, \\ Australia
}

$\mathrm{DHI}$ Water and Environment PO Box 3596

Australia Fair, QLD 4215 ,

Australia

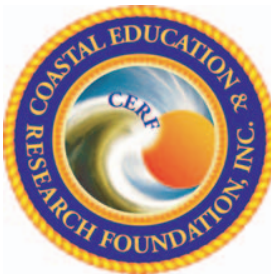

www.cerf-jcr.org

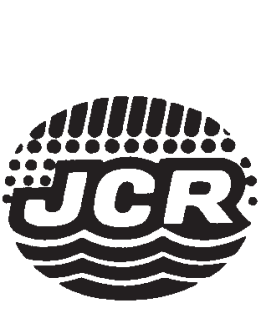

www.JCRonline.org

\begin{abstract}
DUNN, R.J.K.; CATTERALL, K.; HOLLINGSWORTH, A.; KIRKPATRICK, S.; CAPATI, G.; HUDSON, S.; KHAN, S.; PANTHER, J.G.; STUART, G.; SZYLKARSKI, S.; TEASDALE, P.R.; TOMLINSON, R.B., and WELSH, D.T., 2012 Short-term variability of nutrients and fecal indicator bacteria within the Gold Coast Seaway, southern Moreton Bay (Australia). Journal of Coastal Research, 28(1A), 80-88. West Palm Beach (Florida), ISSN 0749-0208.

Significant urban development surrounding the Gold Coast Broadwater and upper catchment has resulted in concerns about degrading water quality of the estuarine system. The Gold Coast Seaway plays an important role in the exchange of estuarine and oceanic waters influencing the intertidal waters of the region. Water quality within the Gold Coast Seaway and the immediately adjacent Broadwater was investigated three times at three sample depths at 13 sample locations. Conductivity, temperature, and depth casts, total (nitrogen and phosphorus) and dissolved inorganic $\left(\mathrm{NO}_{\mathrm{x}}\right.$ and $\mathrm{NH}_{4}^{+}$) nutrients, and fecal indicator bacteria were measured at hourly intervals to compare the water quality under different tidal conditions at each location. Hydrological data were also collected. From these measurements, the intratidal variability of the Seaway waters was determined. Observed current velocities ranged from 0.001 to $0.909 \mathrm{~m} \mathrm{~s}^{-1}$ and 0.018 to $1.8 \mathrm{~m} \mathrm{~s}^{-1}$ during neap and spring tide periods, respectively. Physical parameters and nutrient concentrations demonstrated typical cyclic variations, with the influence of tidal and diurnal cycles apparent. Near minimum and maximum concentrations were generally observed at high and low water, respectively, indicating the influence of oceanic water during flood tides and catchment waters during ebb tides. Significant correlations were observed between surface water salinity values and total nitrogen and phosphorus concentrations. Fecal coliforms and Enterococcus spp. concentrations were low ( $<60$ colony-forming units per $100 \mathrm{~mL}^{-1}$ ), with no significant trends apparent between concentration and sample location, depth, or tidal phase.
\end{abstract}

ADDITIONAL INDEX WORDS: Intratidal variability, water quality, hydrological conditions.

\section{INTRODUCTION}

Coastal environments are an important interface between land and the open ocean, providing habitats for numerous flora and fauna species, including migratory and indigenous birds and commercial and recreational fish (Stumpf and Haines, 1998). They also play a significant role in modifying the flow of matter and energy between terrestrial and open ocean environments (de la Paz, Gómez-Parra, and Forja, 2008), acting as a filter of contaminants and sediments and moder-

DOI: 10.2112/JCOASTRES-D-10-00065.1 received 22 April 2010; accepted in revision 14 July 2010.

* Present address: Asia-Pacific ASA Pty Ltd, PO Box 1679, Surfers Paradise, QLD 4217, Australia.

Present address: Environmental Futures Centre and Griffith School of Environment, Griffith University, Gold Coast Campus, QLD 4222, Australia.

***** Corresponding author. r.tomlinson@griffith.edu.au

(c) Coastal Education \& Research Foundation 2012 ating water quality (Faulkner, 2004), absorbing wave energy, and providing cultural and recreational benefits (Lee at al., 2006). However, many coastal environments have been exposed to rapidly increasing human activities, ensuring ongoing impacts through changes in land use patterns. Coastal waters are the primary recipient of dissolved inorganic nutrients because of changes in land use patterns, including entry by point and diffuse sources of domestic and industrial waste and agricultural and urban drainage (Caraco and Cole, 1999; Downing et al., 1999; Pereira-Filho et al., 2001). Increased nutrient loadings potentially alter the trophic status, affecting dissolved oxygen concentrations (Parker and O'Reilly, 1991; Pennock, Sharp, and Schroeder, 1994), primary productivity (Nixon, 1982), species richness and abundance (Faulkner, 2004), and fishery yields (Cederwall and Elmgren, 1980).

Water quality sampling within dynamic coastal environments presents challenges from continual variations in freshwater inputs, tidal ranges, suspended sediment loads, and atmospheric conditions (Dittmar and Lara, 2001; Fettweis, 


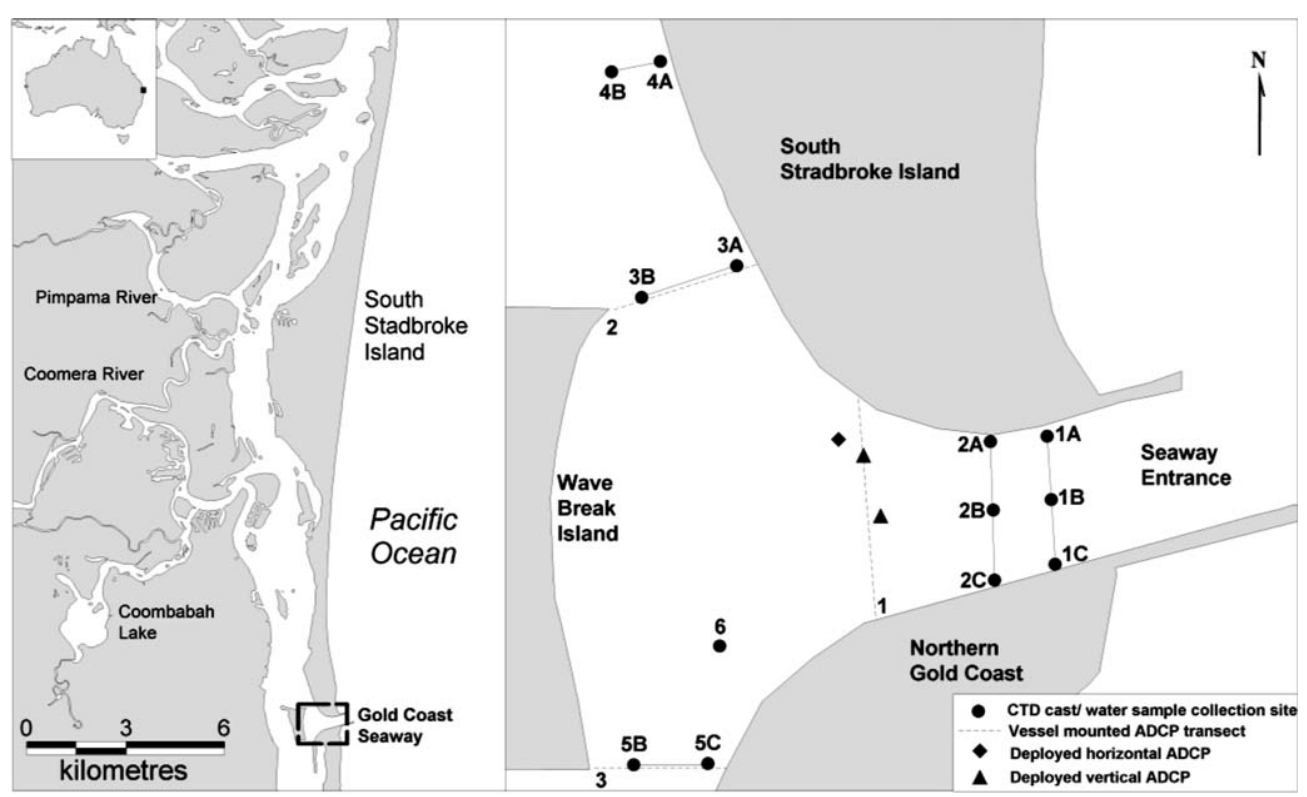

Figure 1. Sampling locations within the Gold Coast Seaway.

Sas, and Monbaliu, 1998; Hyun et al., 1999). Equilibrium conditions are unlikely to be approached, and as a result, determining the variability of key analytes (i.e., trace metals and nutrients) might be more important than determining mean concentrations (Kramer, Brockman, and Warwick, 1994). This often requires use of sophisticated sampling strategies not usually feasible within the time and budget constraints of ongoing monitoring programs undertaken by local authorities. Synoptic sampling, wherein samples are collected simultaneously from multiple sample sites, is regarded as the best sampling strategy within such environments. However, this strategy usually requires a sampling team for each site and is only therefore possible for a limited number of sites (Kramer, Brockman, and Warwick, 1994).

The Gold Coast city located in southern Moreton Bay, southeast Queensland (Australia), is one of the fastest growing regions in the developed world. As a consequence, the region has experienced large-scale urban expansion, including extensive canal and golf course developments along the $250 \mathrm{~km}$ of the region's intertidal waterways and upstream freshwater environments. Many of these waterways flow into the Gold Coast Broadwater, a shallow inshore area that is separated from the Pacific Ocean by two barrier islands (South and North Stradbroke Islands). Changes in land use in the catchment inevitably will contribute to an increase in the run-off of nutrient and sediment loads entering the Broadwater. The southern connection between the Broadwater and the Pacific Ocean is through a man-made navigation channel, the Gold Coast Seaway. The Seaway plays an important role in the ecological health of the intertidal waters of the region, because it influences the exchange of oceanic waters, sediments, organic matter, nutrients, and trace metals between the Broadwater and the Pacific Ocean (Mirfenderesk and Tomlinson, 2008).
As a consequence of the ecological significance and potential for anthropogenic disturbances, processes and mechanisms occurring within the intertidal regions of the Broadwater and Seaway have been the focus of previous scientific efforts (e.g., Ali, Lemckert, and Dunn, 2010; Dunn et al., 2007a; 2007b, 2007c, 2008; Knight et al., 2008; Warnken, Dunn, and Teasdale, 2004). To date, most studies within the Seaway have concentrated on physical and hydrological processes (e.g., Mirfenderesk and Tomlinson, 2007, 2008; Sennes et al., 2007), and as a result, the understanding of biological and chemical dynamics of the Seaway is still limited.

The objective of this study was to provide a comprehensive first account of the intratidal variability of water quality parameters, total (phosphorous [TP] and nitrogen [TN]) and dissolved inorganic $\left(\mathrm{NO}_{\mathrm{x}}\right.$ and $\left.\mathrm{NH}_{4}^{+}\right)$nutrient concentrations and fecal indicator bacteria (fecal coliforms and Enteroccocus spp.) concentrations within the Gold Coast Seaway and adjacent Broadwater. The baseline data collected provides an initial understanding of the system's behavior that will assist future management decisions in this and similar ecologically and economically important urbanized coastal systems. Furthermore, this study provides a database for comparison with future studies within the fast-growing urbanized region.

\section{METHODOLOGY}

\section{Site Description}

This study was undertaken within the Gold Coast Seaway (Figure 1). The Seaway is a $250-\mathrm{m}$-wide, man-made navigation channel averaging $11 \mathrm{~m}$ in water depth, connecting the Gold Coast Broadwater system to the Pacific Ocean. The Broadwater is a typically shallow lagoon system characterized by exposed sandbanks, mangrove islands, and seagrass beds, with 
Table 1. Summary of sample trips, measured parameters, and sample locations.

\begin{tabular}{|c|c|c|c|c|}
\hline Sample Trip & Date & Measured Parameters & $\begin{array}{l}\text { Sample Intervals (relative to } \\
\text { initial daily high water period) }\end{array}$ & $\begin{array}{l}\text { Sample Location and Sample } \\
\text { Depth }\end{array}$ \\
\hline 1 & 10 Feb 09 & $\begin{array}{l}\text { Hydrological parameters; salinity, temperature, } \\
\text { and depth; } \mathrm{NO}_{\mathrm{x}}, \mathrm{TN} \text {, and } \mathrm{TP} \text {; fecal coliforms } \\
\text { and Enterococcus spp. }\end{array}$ & $-1,+1,+2,+3,+5,+7$ & 13 sites (three depths per site) \\
\hline 2 & 23 Mar 09 & $\begin{array}{l}\text { Hydrological parameters; salinity, temperature, } \\
\text { and depth }\end{array}$ & $-1,+1,+2,+3,+5,+7,+9,+10$ & 13 (three depths per site) \\
\hline 3 & 22 Apr 09 & $\begin{array}{l}\mathrm{NO}_{\mathrm{x}}, \mathrm{NH}_{4}^{+}, \mathrm{TN} \text {, and } \mathrm{TP} ; \text { fecal coliforms and } \\
\quad \text { Enterococcus spp. }\end{array}$ & & \\
\hline
\end{tabular}

extensive residential canal and commercial developments on the western shores and a mean tidal range of $1.5 \mathrm{~m}$ (Moss and Cox, 1999). Tidal flows through the Seaway into the Broadwater range from 10 to $40 \times 10^{6} \mathrm{~L}$ (Moss and Cox, 1999), resulting in a very strong flushing effect within the shallow Broadwater. A detailed description of the tidal regime and hydrological characters of the Seaway is presented by Sennes $e t$ al. (2007) and Mirfenderesk and Tomlinson (2008). Freshwater primarily enters the Broadwater via the Nerang, Coomera (north and south arms), and Pimpama Rivers, which is of lesser magnitude than tidal inputs, except after periods of heavy rain (Moss and Cox, 1999). The Nerang, Coomera, and Pimpama River estuaries are approximately 21,17 , and $4 \mathrm{~km}$ in length, respectively. Historically, the region is characterized by approximately 120 days of rainfall per year, with a mean annual rainfall of $1400 \mathrm{~mm}$. Episodically, large inputs of fresh water occur during periods of heavy rainfall, predominantly during summer (December-February). The summer period is characterized by 37 days of rainfall, which accounts for $30 \%$ of the annual regional rainfall.

\section{Study Design}

Physicochemical parameters were monitored and chemical and microbiological water samples were simultaneously collected at 13 sample locations along six transects within the Gold Coast Seaway (Figure 1) from four research vessels. Sample depths at each location included: surface (approximately $0.5 \mathrm{~m}$ from surface waters), middle (mid-water column depth), and bottom ( 0.5-1 m from bottom sediments). Sampling was completed during summer (February) and autumn (March and April) 2009 (Table 1).

Conductivity, temperature, and depth (CTD) casts were conducted at each sample point during water sample collection. Water samples were collected for the determination of nutrient and microbiological parameters, at 1- or 2-hour intervals or at both times for typically 10 hours at all sample locations (Table 1). Each sampling event commenced immediately before morning high-water periods. Additionally, hydrological parameters were measured continuously between February and June 2009 with the use of stationary acoustic Doppler current profilers (ADCPs) and continuously during each sample event with vessel-mounted ADCPs.

Vessel-mounted depth sounders were used to determine water depth at time of sampling, allowing surface, middle, and bottom sample depth determination. Visual observations of the water column characteristics were also recorded during each sample event.

\section{Water Sample Collection and Analysis}

Water samples for the determination of TN, TP, $\mathrm{NO}_{\mathrm{x}}\left(\Sigma \mathrm{NO}_{3}^{-}\right.$ $+\mathrm{NO}_{2}^{-}$), $\mathrm{NH}_{4}^{+}$, fecal coliforms, and Enterococcus spp. concentrations were collected with the use of a horizontal Van Dorn sampler. The contents of the sampler was transferred to an acid-washed $(10 \% \mathrm{HCl})$ and water-rinsed (Milli-Q element water; $18 \mathrm{M} \Omega \mathrm{cm}$, Millipore Pty. Ltd.) container, from which 10$\mathrm{mL}$ subsamples were collected for the determination of total nutrient concentrations. Subsamples were directly transferred by acid- and water-washed $(10 \% \mathrm{HCl})$ and sample-rinsed $50-$ $\mathrm{mL}$ syringes into $10-\mathrm{mL}$ sterilized polystyrene centrifuge tubes for the determination of TN and TP concentrations. Additional $10-\mathrm{mL}$ subsamples were filtered through GF/F membranes (25 mm diameter, Whatman, Floram Park, New Jersey) and transferred into sterilized polystyrene centrifuge tubes with and without the addition of $200 \mu \mathrm{L}$ of $2 \mathrm{M} \mathrm{HCl}$ for the determination of $\mathrm{NH}_{4}^{+}$and $\mathrm{NO}_{\mathrm{x}}$ concentrations, respectively. Additionally, $250 \mathrm{~mL}$ subsamples were collected and transferred to sterilized polystyrene screw-cap containers for the determination of fecal coliforms and Enterococcus spp. concentrations.

All water samples were immediately stored at $<4{ }^{\circ} \mathrm{C}$ in the dark before being transported from the field. Nutrient samples were stored frozen $\left(-20{ }^{\circ} \mathrm{C}\right.$ within $4 \mathrm{~h}$ of collection) awaiting analysis. Biological samples were analyzed immediately on arrival to the laboratory (within $4 \mathrm{~h}$ of collection).

All inorganic nutrient concentrations were determined by an automated colorimetric nutrient analyzer (EasyChem Plus Random Access analyzer, Systea Analytical Technologies, Anagni, Italy) on the basis of standard colorimetric methodologies (APHA, AWWA, and WPCF, 2005). TN and TP samples were digested (potassium persulfate/sodium hydroxide; $2 \times$ $45 \mathrm{~min} ; 120^{\circ} \mathrm{C}$ ) before analysis. Limit of detection concentrations ([blank analysis] standard deviation $\times 3$ ) were 2.01, $0.701,0.133$, and $0.229 \mu \mathrm{g} \mathrm{L^{-1 }}$ for $\mathrm{TN}, \mathrm{TP}, \mathrm{NO}_{\mathrm{x}}$, and $\mathrm{NH}_{4}^{+}$, respectively.

Fecal coliform concentrations were determined according to a membrane filtration method (4276.5; Australian/New Zealand Standards, 2007). Similarly, Enterococcus spp. concentrations were also determined after sample filtration and incubation (method 9222-D; APHA, AWWA, and WPCF, 2005). Microbial results are reported as colony-forming units per $100 \mathrm{~mL}\left(\mathrm{cfu}[100 \mathrm{~mL}]^{-1}\right)$. 


\section{Conductivity, Temperature, and Depth (CTD) Profiles}

Vertical profiles were obtained with the use of weighted YSI (Letchworth, UK) 6600 multiparameter Sonde or RBR (Ottawa, Canada) XR CTD data loggers. Weights were added to each instrument to reduce horizontal drift. Casts were made at each sample site in parallel with the collection of the water samples at a rate of $1 \mathrm{~m}$ per 5 seconds for the first meter and $1 \mathrm{~m}$ per 3 seconds for the remaining depth. Instruments were configured to collect data at 2 -second intervals. Conductivity data are reported as salinity. Data were converted to salinity by YSI EcoWatch (Version 3.18.00) and RBR Software (Version 6.05), respectively, applying the UNESCO practical salinity scale.

\section{Hydrodynamic and Atmospheric Conditions}

Hydrodynamic data (current speed and direction) were measured with the use of stationary and vessel-mounted ACDPs. Current velocities were measured with a vesselmounted ADCP (Sontek) along transects (Figure 1) during each sample day for typically 12 hours. Vertical velocity data were measured at 5 -second intervals. Three stationary ADCPs were also intermittently deployed (Figure 1) from February to June 2009. A horizontally mounted ADCP (Sontek SL500) was attached to a channel marker (Figure 1) at a depth of approximately $4 \mathrm{~m}$ below the water surface placed in a direction of $212^{\circ}$ (from north) from 25 February to 11 June. Velocity profiles were collected at intervals of 20 (25 February 2009 to 19 March 2009) and 10 minutes (19 March 2009 to 11 June 2009) for a sample period of 120 seconds. Seabed (vertically) mounted ADCPs (Sontek XR, San Diego, California, and Flowquest, San Diego, California) were configured to sample vertical velocity profiles for 6-minute and 10-second periods at 30-minute intervals during each deployment period. Data were averaged across the width and height of each cell. All instruments were deployed intermittently between 1 February and 11 June.

\section{Meteorological Measurements}

Meteorological data were obtained from the Australian Bureau of Meteorology weather stations located at Hinze Dam ( $\sim 20 \mathrm{~km}$ from the Seaway), at Coomera ( $\sim 6 \mathrm{~km}$ from the Seaway), and immediately at the Gold Coast Seaway. Rainfall recorded at Hinze Dam and Coomera are representative of the Nerang and northern Gold Coast catchments, respectively.

\section{Statistical Analysis}

Descriptive statistics, $\mathrm{t}$ test analyses, analysis of variance (ANOVA), and Pearson correlations were used to explore data sets and identify relationships between hydrodynamic conditions, physical variables, water column nutrients, and bacterial concentrations, respectively, with SPSS for Windows (version 11.5.0, SPSS Inc., Chicago, Illinois). A criteria of $p<0.05$ was used to determine statistical significance at the 0.05 level (twotailed. In all instances, data did not require transformation. Descriptive statistics included the determination of the minimum, maximum, mean, standard deviation, and percent relative standard deviation (\% rsd) of individual data sets.
Nutrient and microbiological concentrations were compared with the Broadwater subregion values within the Queensland Water Quality Guidelines (QWQG) (QEPA, 2006) and the Australian and New Zealand Environmental Conservation Council (ANZECC, 2000) Water Quality Guidelines.

\section{RESULTS AND DISCUSSION}

\section{Meteorological Conditions and Visual Observations}

No rainfall was recorded during any sampling trip; however, rainfall events in the surrounding catchments were recorded within a 7-day period before trips 1 and 2. Subsequently, all sampling was considered as a representation of "dry" conditions. Wind speed and direction varied between and during each sampling trip, with increased mean speeds occurring in the afternoon period $\left(\sim 30 \mathrm{~km} \mathrm{~h}^{-1}\right)$. Air temperatures ranged between 18.2 and $31.4{ }^{\circ} \mathrm{C}$ at the Seaway. Water clarity decreased during periods coinciding with maximum wind speeds and flood tide periods. Consistent increases in turbidity at the Seaway during low water have previously been documented (Moss and Cox, 1999). During each sample trip, water clarity was greatest during periods of high water, particularly during the morning period when wind speeds were largely reduced. Alternatively, water clarity was greatly reduced either side of low water as a result of observed increased suspended particulate matter (SPM) loadings. This period coincided with increased wind speeds during the afternoon. The influence of propeller wash scouring surface sediments and acting as a source of suspended sediments (Beachler and Hill, 2003; Schoellhammer, 1996; Smart et al., 1985) should not be discounted within the major navigational channel between the Gold Coast Broadwater and Pacific Ocean. The resuspension of sediments and increased SPM concentrations within coastal systems has been documented and affect the physical conditions of the system and the associated organisms within (Harvey and Caton, 2003; van Rijn, 1993). Periodic increases of sediment resuspension could represent a source of increased nutrient flux (Morin and Morse, 1999; Simon, 1989).

\section{Hydrodynamic Conditions}

Observed current velocities ranged from 0.001 to $0.909 \mathrm{~m} \mathrm{~s}^{-1}$ and 0.018 to $1.82 \mathrm{~m} \mathrm{~s}^{-1}$ during the neap and spring tide periods, respectively. Maximum currents were recorded by the horizontally deployed ADCP (Figure 2). Measured current velocities were generally uniform throughout the water column with respect to depth and indicated a typically sustained reduction in magnitude at a distance of $41.5-51.5 \mathrm{~m}$ from the ADCP. This identified zone of reduced current speed is supported by data collected from the vertically mounted ADCPs (individual data not shown). Typically, tidal flow at tidal entrances is characterized by asymmetry, with higher peak current velocities and shorter durations of flow during flood tides (Braddock, Lee, and Tomlinson, 2000; Tomlinson 1990); however, no clear pattern of tidal asymmetry was observed during the monitoring period. Dominant flow directions during the flood and ebb tide periods ranged from $260^{\circ}$ to $290^{\circ}$ and $100^{\circ}$ to $110^{\circ}$, respectively. At the southern ADCP, flow reversal during flood-to-ebb and ebb-to- 

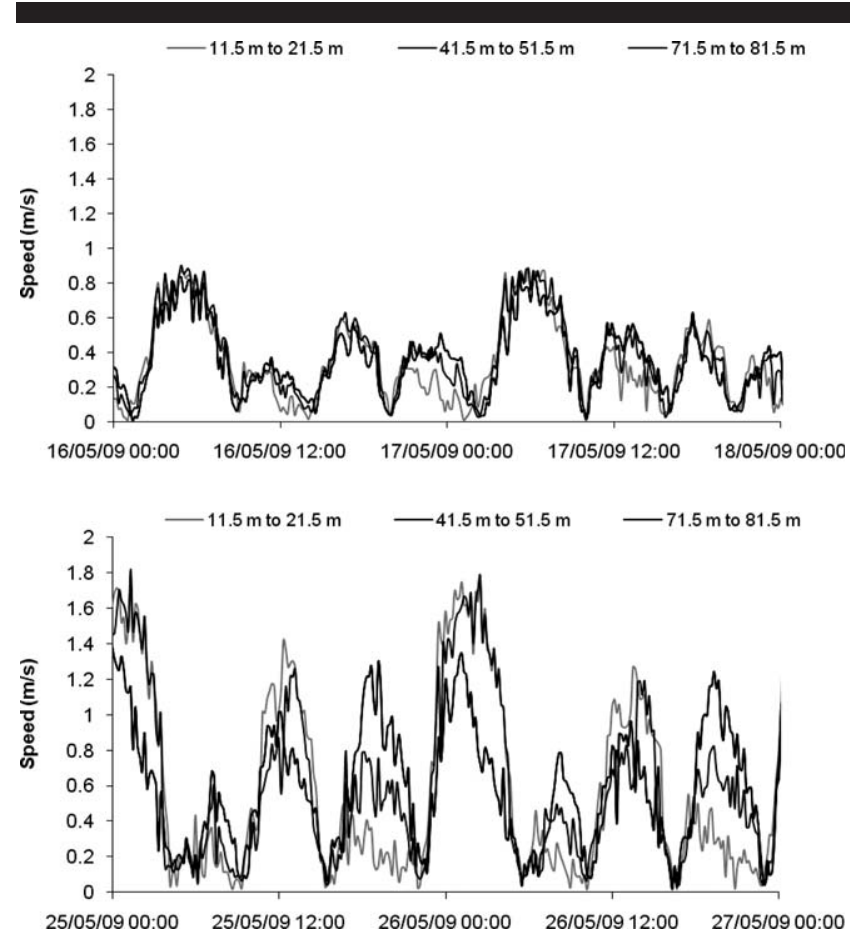

Figure 2. Snapshot of current speed measured at select distances from the horizontal ADCP during a neap tide period (top) and spring tide period (bottom).

flood tidal phase changes were identified typically to occur $1 \mathrm{~h}$ before the corresponding flow reversal observed at the northern vertically and horizontally deployed ADCP, presumably as a result of the identified zone of reduced current velocities occurring approximately $50 \mathrm{~m}$ from the northern seawall. Flow rates ranged approximately between -3800 and $4000 \mathrm{~m}^{3} \mathrm{~s}^{-1}$ between ebb and flood tides, respectively. Maximum flow rates were observed during the flood tide period along the Seaway entrance (transect 1, Figure 1). Flow rates were significantly greater $(p<0.001, \alpha=0.05)$ across the northern channel (transect 2, $2183 \pm 1092 \mathrm{~m}^{3} \mathrm{~s}^{-1}$ ) compared with the southern channel (transect $3,1534 \pm 746.0 \mathrm{~m}^{3} \mathrm{~s}^{-1}$ ) supporting previous findings of Mirfenderesk and Tomlinson (2007). Seasonal variability of flow volumes with respect to the magnitude of mean flow is to be expected within the system. This current study does not take into account such seasonal events, including periods of heavy rainfall, in which case flow values would be expected to increase significantly.

\section{Physical Variables}

Depth-averaged salinity and temperature values showed characteristic cyclic variations, with the influence of tidal and diurnal irradiance cycles apparent (Figure 3). Variability was characterized by $\%$ rsd measures of 3.98 and 6.21 for salinity and temperature, respectively. Salinity values ranged from 25.1 to 35.6 and were significantly greater $(p<0.001, \alpha=0.05)$ during high-water periods $(34.87 \pm 0.64)$ coinciding with the increased flux of oceanic waters through the Seaway. The low water mean salinity value was $33.54 \pm 1.33$. Although no
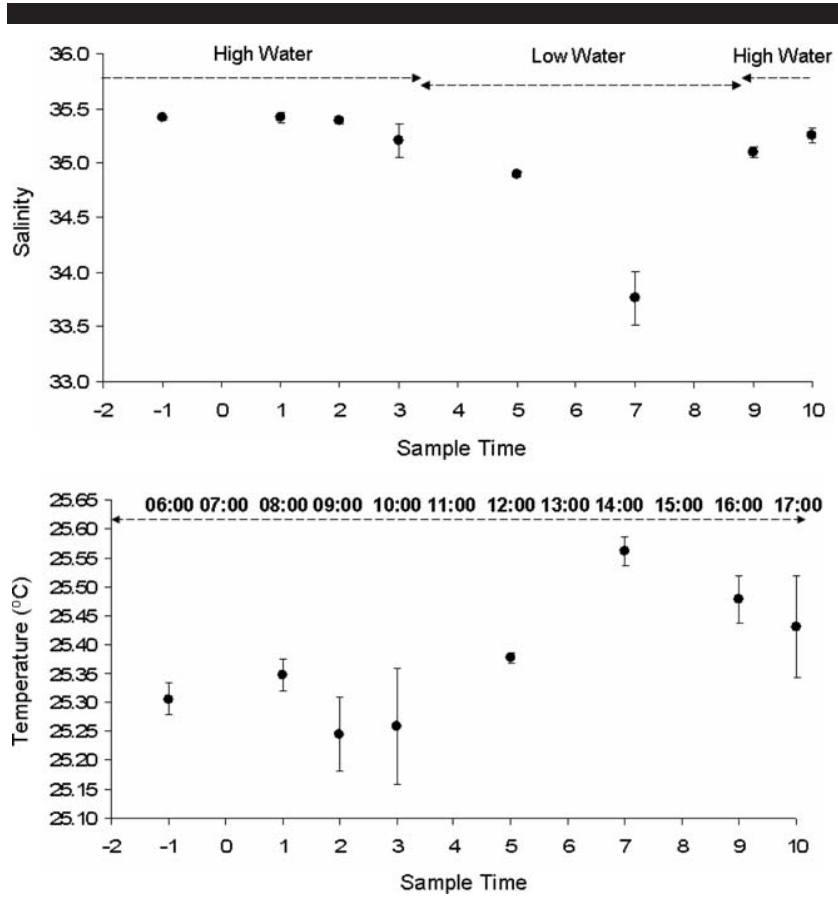

Figure 3. Depth-averaged time series plot of mean \pm standard deviation (a) salinity and (b) temperature values recorded at sample location $2 \mathrm{~B}$ during sample trip 2 (sample time 0 indicates the initial high water period).

significant difference was observed between sample sites, surface water salinity values were typically lower at sites 1 and 2 during the ebb tide periods, presumably as a result of the release of recycled waters from diffusers situated along the northern seawall (Kirkpatrick and Hughes, 2009; Moss and Cox, 1999; Stuart et al., 2009). The Coombabah waste water treatment plant releases excess recycled water from the northern Seaway wall through a diffuser system, which releases approximately $110 \mathrm{ML}$ of recycled water per day (Stuart et al., 2009). Under typical operating conditions, recycled water is released on the ebb tide (on the basis of predicted local tide times) at the Seaway entrance, allowing the recycled water to be dispersed to the Pacific Ocean while limiting the amount of excess recycled water returning into the Seaway (and Broadwater) on the next flood tide (Stuart et al. 2009). In addition to spatial salinity profiles, depth salinity profiles also indicated no significant difference between sample depths, demonstrating a well-mixed semidiurnal tidal system. Water temperature varied according to water column depth and time of day, with temperatures ranging from 22.1 to 30.5 ${ }^{\circ} \mathrm{C}$. Elevated water temperatures coincided with increases in air temperatures observed during the afternoon period $(+7,+9$, and +10 hour samplings), and maximum water temperatures typically decreased during the flood tide periods (Figure 3).

\section{Total and Dissolved Inorganic Nutrients}

Combined sample trip depth-averaged percentile and mean concentrations for each transect are shown in Table 2. No significant differences were observed with changes in sample 
Table 2. Combined sample depth-averaged nutrient concentrations for sample transect $\left(\mu g L^{-1}\right)$.

\begin{tabular}{|c|c|c|c|c|c|c|}
\hline \multirow[b]{2}{*}{ Site } & \multicolumn{3}{|c|}{ Percentile } & \multirow[b]{2}{*}{ Mean } & \multirow[b]{2}{*}{ SD } & \multirow[b]{2}{*}{$\%$ rsd } \\
\hline & 20 & 50 & 80 & & & \\
\hline \multicolumn{7}{|c|}{ Total nitrogen (limit of detection $=2.01$ ) } \\
\hline 1 & 173 & 254 & 383 & 280 & 125 & 44.8 \\
\hline 2 & 206 & 315 & 450 & 338 & 150 & 44.4 \\
\hline 3 & 208 & 296 & 473 & 337 & 142 & 42.0 \\
\hline 4 & 237 & 339 & 505 & 362 & 152 & 42.0 \\
\hline 5 & 211 & 284 & 425 & 316 & 122 & 38.7 \\
\hline \multirow[t]{2}{*}{6} & 313 & 389 & 462 & 370 & 88.8 & 24.0 \\
\hline & 130 & 150 & 190 & \multicolumn{3}{|c|}{$\begin{array}{l}\text { Broadwater subregional } \\
\text { guideline values }\end{array}$} \\
\hline
\end{tabular}

Total phosphate (limit of detection $=0.701$ )

\begin{tabular}{|c|c|c|c|c|c|c|}
\hline 1 & 7.09 & 16.4 & 30.5 & 20.3 & 15.6 & 76.8 \\
\hline 2 & 8.61 & 19.9 & 33.1 & 24.3 & 19.8 & 81.5 \\
\hline 3 & 6.92 & 14.5 & 25.0 & 16.7 & 13.0 & 77.7 \\
\hline 4 & 5.94 & 14.9 & 24.7 & 16.1 & 11.2 & 69.7 \\
\hline 5 & 4.78 & 14.7 & 23.8 & 15.6 & 11.6 & 74.6 \\
\hline 6 & 4.15 & 6.69 & 19.2 & 13.3 & 11.6 & 87.3 \\
\hline & 14 & 17 & 22 & $\begin{array}{r}\text { Broadr } \\
\text { guic }\end{array}$ & & $a l$ \\
\hline
\end{tabular}

Nitrite + nitrate (limit of detection $=0.133$ )

\begin{tabular}{ccccccc}
1 & 4.30 & 9.28 & 16.7 & 13.5 & 16.4 & 121 \\
2 & 4.17 & 9.27 & 18.7 & 16.2 & 24.9 & 154 \\
3 & 4.20 & 8.09 & 12.0 & 8.31 & 4.73 & 57.3 \\
4 & 3.73 & 8.44 & 12.5 & 10.0 & 10.3 & 102 \\
5 & 4.64 & 8.87 & 12.9 & 10.9 & 11.7 & 108 \\
6 & 2.81 & 8.74 & 11.2 & 8.25 & 4.95 & 59.9 \\
& 2 & 2 & 4 & Broadwater subregional \\
& & \multicolumn{5}{c}{ guideline values }
\end{tabular}

Ammonium (limit of detection $=0.229$ )

\begin{tabular}{rcccccr}
1 & 3.98 & 10.0 & 17.9 & 11.3 & 7.53 & 66.7 \\
2 & 5.28 & 10.3 & 17.4 & 11.5 & 7.75 & 67.2 \\
3 & 5.04 & 10.6 & 15.9 & 11.6 & 7.34 & 63.5 \\
4 & 6.10 & 11.5 & 17.7 & 12.2 & 6.90 & 56.5 \\
5 & 6.81 & 12.0 & 18.7 & 12.9 & 6.90 & 53.5 \\
6 & 4.05 & 8.36 & 11.1 & 12.6 & 8.81 & 69.9 \\
& 2 & 4 & 8 & Broadwater subregional \\
& & \multicolumn{5}{c}{ guideline values } \\
\hline
\end{tabular}

$\mathrm{SD}=$ standard deviation; $\% \mathrm{rsd}=$ relative standard deviation

location and water depth. Total nitrogen and phosphate concentrations ranged from 12.4 to $845 \mu \mathrm{g} \mathrm{\textrm {L } ^ { - 1 }}$ and 0.743 to $110 \mu \mathrm{g} \mathrm{L}{ }^{-1}$, with a mean concentration of $326 \pm 141 \mu \mathrm{g} \mathrm{L}^{-1}$ and $18.9 \pm 15.4 \mu \mathrm{g} \mathrm{L}^{-1}$, respectively (Figure 4). Depth-averaged TN concentration exceeded the Broadwater QWQG concentrations (190 $\mu \mathrm{g} \mathrm{L}^{-1}$; Table 2). The 80th percentile TP concentrations exceeded the Broadwater QWQG concentration $\left(22 \mu \mathrm{g} \mathrm{L}^{-1}\right)$. Mean Seaway $\mathrm{NO}_{\mathrm{x}}$ concentration was $12.2 \pm 16.3 \mu \mathrm{g} \mathrm{L}^{-1}$ and exceeded the Broadwater QWQG $\left(4 \mu \mathrm{g} \mathrm{L}^{-1}\right)$. Ammonium concentrations ranged between 0.03 and $46.1 \mu \mathrm{g} \mathrm{L} \mathrm{L}^{-1}$, with a mean concentration of $11.7 \pm 7.32 \mu \mathrm{g} \mathrm{\textrm {L } ^ { - 1 }}$, which also exceeded the Broadwater QWQG values. The variability of TN, TP, $\mathrm{NO}_{\mathrm{x}}$, and $\mathrm{NH}_{4}^{+}$concentrations across all sample sites was characterized by measures of $43.1,81.6,134$, and $62.3 \% \mathrm{rsd}$, respectively. Nutrient concentrations were typical of concentrations reported in Australian and local coastal waters (Abal and Dennison, 1996; Cox and Moss, 1999; Dunn et al., 2007a; Moss and Cox, 1999) and specifically compare well to concentrations previously reported within the Seaway during “dry” sample periods by Moss and Cox (1999).

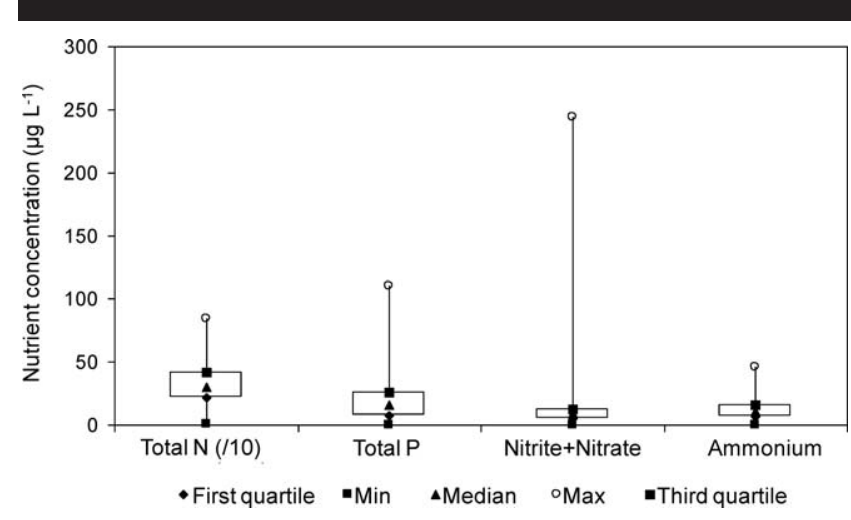

Figure 4. Combined mean total and dissolved inorganic nutrient concentration box plot representation.

Filterable and total dissolved inorganic nutrient concentrations demonstrated significant differences between sample times during sample trips ( $p<0.05, \alpha=0.05$ ). Concentrations typically demonstrated a pattern with respect to the high and low tide phases with near minimum and maximum concentrations observed during high and low water, respectively (Figure 5). This pattern is presumably a result of mixing of the enclosed coastal waters of the Broadwater and the waters of the adjacent Pacific Ocean. Water quality in the Broadwater is influenced by flushing of oceanic waters during flood tides and by water quality in the two urbanized tributaries, the Nerang and Coomera Rivers, which provide nutrient sources and freshwater inflow into the Broadwater during ebb tides. Rainfall events have been shown to increase the influx of trace metals, nutrients, and suspended sediment concentrations into intertidal waters connected to the Broadwater (Dunn et al., 2007c; Teasdale et al., 2009; Tomlinson et al., 2005, 2006).

Additionally, elevated nutrient concentrations appeared to coincide with observed periods of increased SPM, which have previously been shown to constitute a source of nutrients (Gao, Li, and Ding, 2008; Rocha, Cabeçadas, and Brogueira, 1995; Valdes and Real, 1998). The pattern of nutrient concentrations in the Broadwater and ocean could be expected to be altered by

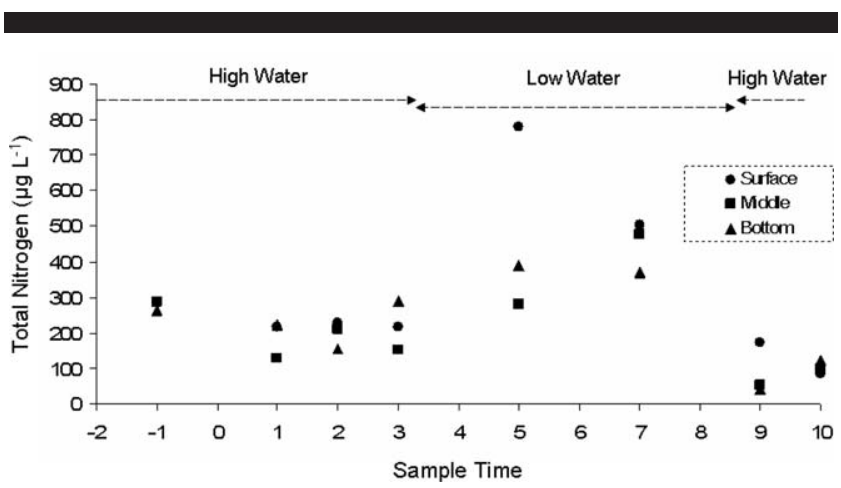

Figure 5. Time series plot of mean \pm standard deviation total nitrogen concentration for surface, middle, and bottom waters recorded at sample location $2 \mathrm{~B}$ during sample trip 2 (sample time 0 indicates the initial high water period). 
the release of recycled water at the Seaway (Moss and Cox, 1999). If the release of recycled waters significantly increased nutrient concentrations during the release period (ebb tides), this would be expected in the vicinity of the release plume (sites 2A, 1A). However, significant increases in concentrations were not consistent within the expected plume vicinity during release for each sampling trip. Furthermore, during the release phase, waters from the upper tributaries are being exported from the Broadwater, making the assessment of the relative contributions of catchment inputs and nutrients sourced from the released recycled waters difficult.

This study does not aim to quantify the influence of surrounding catchments or the release of recycled water within the Seaway but, rather, acknowledge their potential influence on the observed variability within the system. Investigations relating to the capacity of the Broadwater to assimilate a greater quantity of recycled water and the optimization of the release system have previously been undertaken (Rasch, Davies, and Chiffings 2007; Stuart et al., 2009).

Earlier comparisons of water quality within the Seaway suggest that run-off from the Nerang River catchment entering the Broadwater during rainfall events has a greater effect on nutrient concentrations than the release of recycled waters within the Seaway (Moss and Cox, 1999). Teasdale et al. (2009) demonstrated that rainfall (>65 $\mathrm{mm}$ over $24 \mathrm{~h}$ ) had a significant influence on nutrient (total dissolved nitrogen, $\mathrm{NO}_{\mathrm{x}}, \mathrm{NH}_{4}^{+}$, total dissolved phosphorous, and $\mathrm{PO}_{4}^{3-}$ ) concentrations in the Saltwater Creek estuary within the Broadwater, increasing concentrations by up to $>500 \%$ compared with dry periods.

During this study, significant correlations were observed between surface water salinity values and TN $(r=-0.325, p<$ $0.001, \alpha=0.05)$ and TP $(r=-0.364, p<0.001, \alpha=0.05)$ concentrations during sampling performed during "dry" conditions.

Nutrient data collected provides a snapshot of the conditions throughout the sampling period and does not necessarily reflect the long-term trends in water quality or conditions during rainfall periods that were not encountered during the study. During heavy rainfall events, industrial and commercial developments, waterfront housing, and impervious surfaces within the catchment and foreshores act as point and diffuse nutrient sources. Elevated TN and TP concentrations during low water also coincided with observed increased suspended sediment loads within the sampled waters.

\section{Fecal Indicator Bacteria}

Concentrations of fecal indicator bacteria were relatively low and ranged from 0 to $52 \mathrm{cfu}(100 \mathrm{~mL})^{-1}$ for fecal coliform and 0 to $58 \mathrm{cfu}(100 \mathrm{~mL})^{-1}$ for Enterococcus spp. (Table 3). Mean fecal coliform and Enterococcus spp. concentrations were all well below water quality guideline values of $150 \mathrm{cfu}(100 \mathrm{~mL})^{-1}$ and $35 \mathrm{cfu}(100 \mathrm{~mL})^{-1}$, respectively (ANZECC, 2000). No significant difference was observed between sample locations or sample depths, with variability ranging from 71 to $136 \%$ rsd and 71 to $203 \%$ rsd for fecal coliforms and Enterococcus spp., respectively. No trends were apparent with respect to concentration and sample time during each sample trip. Furthermore, no
Table 3. Combined depth-averaged microbiological concentrations for each sample transect from sample trips 1, 2, and 3 .

\begin{tabular}{|c|c|c|c|c|c|}
\hline Site & Minimum & Maximum & Mean & $\mathrm{SD}$ & $\%$ rsd \\
\hline \multicolumn{6}{|c|}{ Fecal coliforms $\left(\mathrm{cfu}[100 \mathrm{~mL}]^{-1}\right)$} \\
\hline 1 & 0.0 & 52 & 7.2 & 9.8 & 136 \\
\hline 2 & 0.0 & 45 & 9.1 & 8.9 & 98.1 \\
\hline 3 & 1.0 & 23 & 5.0 & 4.1 & 80.3 \\
\hline 4 & 0.0 & 36 & 5.3 & 5.6 & 104 \\
\hline 5 & 0.0 & 46 & 10 & 9.8 & 97.0 \\
\hline 6 & 0.0 & 12 & 5.2 & 3.7 & 71.2 \\
\hline \multicolumn{6}{|c|}{ Enterococci spp. $\left(\mathrm{cfu}[100 \mathrm{~mL}]^{-1}\right)$} \\
\hline 1 & 0.0 & 58 & 3.4 & 6.9 & 203 \\
\hline 2 & 0.0 & 36 & 3.1 & 4.6 & 149 \\
\hline 3 & 0.0 & 7 & 2.3 & 1.7 & 71.0 \\
\hline 4 & 0.0 & 10 & 2.2 & 1.8 & 82.9 \\
\hline 5 & 0.0 & 32 & 4.1 & 5.4 & 130 \\
\hline 6 & 0.0 & 14 & 3.5 & 4.5 & 128 \\
\hline
\end{tabular}

$\mathrm{SD}=$ standard deviation; $\% \mathrm{rsd}=$ relative standard deviation

significant correlation was observed between microbiological concentrations and salinity. No significant trends were observed between microbiological concentrations and the release of recycled water during ebb tide cycles within the Seaway.

\section{CONCLUSION}

The results of this study illustrate the dynamic and wellmixed environment of the Seaway channel and adjacent Broadwater. The Broadwater was strongly influenced by tidal flow during the sample period, with maximum flow velocities recorded of $1.82 \mathrm{~m} \mathrm{~s}^{-1}$. The Broadwater also exhibits the typical characteristics of a shallow estuary, including a phase lag between the tide level and the flow reversal. Salinity, temperature, and depth data collected over the sampling period also reflected a well-mixed, dynamic system, with no notable stratification within the Seaway channel. Physical parameters and nutrient concentrations within the Seaway typically demonstrated cyclic variations, with the influence of tidal and diurnal irradiance cycles apparent. No trends were observed relative to fecal indicator bacteria concentrations within the Seaway during the study. Parameter variability ranged from 3.98 to $203 \%$ rsd, with salinity and Enterococcus spp. concentrations characterized by the smallest and largest intratidal variability, respectively. Mean total and dissolved inorganic nutrient concentrations typically demonstrated an increasing pattern with respect to the high and low tide phases, with near minimum and maximum concentrations observed during high and low water, respectively. Nutrient concentrations exceeded Broadwater QWQG values. Fecal coliforms and Enterococcus spp. concentrations were low, with no significant trends apparent between concentration and sample location, depth, or tidal phase.

This study provides the first comprehensive account of the intratidal variability of water quality parameters, total and dissolved inorganic nutrient concentrations, and fecal indicator bacteria concentrations within the sampled waters. Data collected during this study provide a snapshot of the conditions throughout the sampling period but do not necessarily reflect the long-term trends in water quality or conditions during 
heavy rainfall periods, which were not encountered during the study. Future assessments of riverine influences are required to provide an understanding of intertidal and event-specific variations of the physicochemical and biogeochemical processes in the ecologically significant region of the Gold Coast Seaway, which is an important link between the Gold Coast Broadwater and the Pacific Ocean.

\section{ACKNOWLEDGMENTS}

The authors gratefully acknowledge the peer review role provided by the South-East Queensland Healthy Waterways Partnership and the technical advice provided by the Department of Environment and Resource Management. Funding for this study was provided by Gold Coast City Council, and the fieldwork was undertaken by the Griffith University Center for Coastal Management and overseen by DHI Water and Environment.

\section{LITERATURE CITED}

Abal, E.G. and Dennison, W.C., 1996. Seagrass depth range and water quality in southern Morton Bay, Queensland, Australia. Marine and Freshwater Research, 47, 763-771.

Ali, A.; Lemckert, C.J., and Dunn, R.J.K., 2010. Salt fluxes within a very shallow sub-tropical estuary. Journal of Coastal Research, 26(3), 436-443.

ANZECC (Australian and New Zealand Environment and Conservation Council), 2000. Australian and New Zealand Guidelines for Fresh and Marine Water Quality Volume 2-Rationale and Background Information. Canberra, Australia: Australian and New Zealand Environment and Conservation Council, Agriculture and Resource Management of Australia, pp. 8.1-1-8.5-14.

APHA (American Public Health Association), AWWA (American Water Works Association), and WPCF (Water Pollution Control Federation), 2005. Standard Methods for Examination of Water and Wastewater, 21st edition. Washington, DC: American Public Health Association, 1368p.

Australian/New Zealand Standards, 2007. Water Microbiology Method 5: Coliforms-Membrane Filtration Method. Sydney, Australia: Standards Australia/Standards New Zealand AS/NZS 4276.5.

Beachler, M.M. and Hill, D.F., 2003. Stirring up trouble? Resuspension of bottom sediments by recreational watercraft. Lake and Reservoir Management, 19(1), 15-25.

Braddock, R.D.; Lee, H., and Tomlinson, R.B., 2000. River inlets and tidal draw. In: Noye, B.J. (ed.), Modelling Coastal Sea Processes. Singapore: World Scientific Publishing, pp. 293-316.

Caraco, N. and Cole, J.J., 1999. Regional export of C, N, P and sediment: what river data tell us about key controlling variables. In: Tenhunen, J.D. and Kabat, P. (eds.), Integrating Hydrology, Ecosystem Dynamics and Biogeochemistry in Complex Landscapes. New York: John Wiley and Sons, pp. 239-253.

Cederwall, H. and Elmgren, R., 1980. Biomass increase of benthic macrofauna demonstrates eutrophication of the Baltic Sea. Ophelia, 1, S287-S304.

Cox, M. and Moss, A., 1999. Nerang River, Tallebudgera, Currumbin and Coombabah Creeks: Water Quality Report 1999. Brisbane, Australia: Queensland Environmental Protection Agency, 26p.

de la Paz, M.; Gómez-Parra, A., and Forja, J., 2008. Tidal-to-seasonal variability in the parameters of the carbonate system in a shallow tidal creek influenced by anthropogenic inputs, Rio San Pedro (SW Iberian Peninsula). Continental Shelf Research, 28(10-11), 13941404.

Dittmar, T. and Lara, R.J., 2001. Driving forces behind nutrient and organic matter dynamics in a mangrove tidal creek in north Brazil. Estuarine, Coastal and Shelf Science, 52(2), 249-259.

Downing, J.A.; McClain, M.; Twilley, R.; Melack, J.M.; Elser, J.; Rabalais, N.N.; Lewis, W.M., Jr.; Turner, R.E.; Corredor, J.; Soto,
D.; Yanez-Arancibia, A.; Kopaska, J.A., and Howarth, R.W., 1999. The impact of accelerating land use change on the N-cycle of tropical aquatic ecosystems: current conditions and projected changes. Biogeochemistry, 46(1-3), 109-148.

Dunn, R.J.K.; Ali, A.; Lemckert, C.J.; Teasdale, P.R., and Welsh, D.T., 2007a. Short-term variability of physico-chemical parameters and the estimated transport of filterable nutrients and chlorophyll- $a$ in the urbanised Coombabah Lake and Coombabah Creek system, southern Moreton Bay, Australia. Journal of Coastal Research 50(SI), 1062-1068.

Dunn, R.J.K.; Lemckert, C.J.; Teasdale, P.R., and Welsh, D.T., 2007b. Distribution of nutrients in surface and sub-surface sediments of Coombabah Lake, southern Moreton Bay (Australia). Marine Pollution Bulletin, 54, 606-614.

Dunn, R.J.K.; Teasdale, P.R.; Warnken, J.; Jordan, M. A., and Arthur, M., 2007c. Evaluation of the time-integrated, in situ DGT technique by monitoring changes in heavy metal concentrations in estuarine waters in response to natural and anthropogenic processes. Environmental Pollution, 148, 213-220.

Dunn, R.J.K.; Welsh, D.T.; Lee, S.Y.; Lemckert, C.J.; Teasdale, P.R., and Meziane, T., 2008. Investigating the distribution and sources of organic matter in surface sediment of Coombabah Lake (Australia) using elemental, isotopic and fatty acid biomarkers. Continental Shelf Research, 28(18), 2535-2549.

Faulkner, S., 2004. Urbanization impacts on the structure and function of forested wetlands. Urban Ecosystems, 7(2), 89-106.

Fettweis, M.; Sas, M., and Monbaliu, J., 1998. Seasonal, neap-spring and tidal variation of cohesive sediment concentration in the Scheldt Estuary, Belgium. Estuarine, Coastal and Shelf Science, 47(1), 21-36.

Gao, L.; Li, D.-J., and Ding, P.-X., 2008. Variation of nutrients in response to the highly dynamic suspended particulate matter in the Changjiang (Yangtze River) plume. Continental Shelf Research, 28(17), 2393-2403.

Harvey, N. and Caton, B., 2003. Coastal Management in Australia. Melbourne: Oxford University Press, 342p.

Hyun, J.-H.; Choi, J.K.; Chung, K.H.; Yang, E.-J., and Kim, M.-K., 1999. Tidally induced changes in bacterial growth and viability in the macrotidal Han River Estuary, Yellow Sea. Estuarine, Coastal and Shelf Science, 48(2), 143-153.

Kirkpatrick, S. and Hughes, L., 2009. The Gold Coast Seaway SmartRelease Study: Monitoring Campaign. Gold Coast: Griffith Centre for Coastal Management, Griffith University, Research Report, 302p.

Knight, J.M.; Dale, P.E.R.; Dunn, R.J.K.; Broadbent, G.J., and Lemckert, C.J., 2008. Patterns of tidal flushing within a mangrove forest: Lake Coombabah, South East Queensland Australia. Estuarine, Coastal and Shelf Science, 76(3), 580-593.

Kramer, K.J.M.; Brockman, U.H., and Warwick, R.M., 1994. Tidal Estuaries: Manual of Sampling and Analytical Procedures. Rotterdam: A.A. Balkema Publishing, 314p.

Lee, S.Y.; Dunn, R.J.K.; Young, R.A.; Connolly, R.M.; Dale, P.E.R.; Dehayr, R.; Lemckert, C.J.; McKinnon, S.; Powell, B.; Teasdale, P.R., and Welsh, D.T., 2006. Impact of urbanization on coastal wetland structure and function. Austral Ecology, 31, 149-163.

Mirfenderesk, H. and Tomlinson, R., 2007. Numerical modelling of tidal dynamic and water circulation at the Gold Coast Broadwater, Australia. Journal of Coastal Research, 50(SI), 277-281.

Mirfenderesk, H. and Tomlinson, R., 2008. Observation and analysis of hydrodynamic parameters in tidal inlets in a predominantly semidiurnal regime. Journal of Coastal Research, 24(5), 1229-1239.

Morin, J. and Morse, J.W., 1999. Ammonium release from resuspended sediments in the Laguna Madre estuary. Marine Chemistry, 65, 97-110.

Moss, A. and Cox, M., 1999. Southport Broadwater and Adjacent Pacific Ocean: Water Quality Study 1979-1998. Brisbane, Australia: Queensland Environmental Protection Agency, 28p.

Nixon, S.W., 1982. Nutrient dynamics, primary production and fisheries yields of lagoons. Oceanologica Acta, S357-S371.

Parker, C.A. and O'Reilly, J.E., 1991. Oxygen depletion in Long Island Sound: a historical perspective. Estuaries, 14(3), 248-264.

Pennock, J.R.; Sharp, J.H., and Schroeder, W.W., 1994. What controls 
the expression of estuarine eutrophication? Case studies of nutrient enrichment in the Delaware Bay and Mobile Bay Estuaries, USA. In: Dyer, K.R. and Orth, R.J. (eds.), Changes in Fluxes in Estuaries. International Symposium Series. Fredensborg, Denmark: Olsen and Olsen, pp. 139-146.

Pereira-Filho, J.; Schettini, C.A. F.; Rörig, L., and Siegle, E., 2001. Intratidal variation and net transport of dissolved inorganic nutrients, POC and chlorophyll $a$ in the Camboriú River estuary, Brazil. Estuarine, Coastal and Shelf Science, 53(2), 249-257.

Queensland Environmental Protection Agency, 2006. Queensland Water Quality Guidelines. Brisbane, Australia: Queensland Environmental Protection Agency Publication, 121p.

Rasch, P.; Davies, S., and Chiffings, T., 2007. Broadwater Assimilative Capacity Study: Advection Dispersion Model. Gold Coast, Australia: DHI Water and Environment Pty Ltd. Final Report, 49p.

Rocha, C.; Cabeçadas, G., and Brogueira, M.J., 1995. On the importance of sediment-water exchange processes of ammonia to primary production in shallow areas of the Sado estuary (Portugal). Netherlands Journal of Aquatic Ecology, 29(3-4), 265-273.

Schoellhammer, D.H., 1996. Anthropogenic sediment resuspension mechanisms in a shallow microtidal estuary. Estuarine, Coastal and Shelf Science, 43, 533-548.

Sennes, G.; Castelle, B.; Bertin, X.; Mirfenderesk, H., and Tomlinson, R.B., 2007. Modelling of the Gold Coast Seaway tidal inlet, Australia. Journal of Coastal Research 50(SI), 1086-1091.

Simon, S.S., 1989. Nitrogen cycling between sediment and the shallow-water column in the transition zone of the Potomac River and Estuary. II. The role of wind-driven resuspension and adsorbed ammonium. Estuarine, Coastal and Shelf Science, 28(5), 531-547.

Smart, M.M.; Rada, R.G.; Nielsen, D.N., and Claflin, T.O., 1985. The effect of commercial and recreational traffic on the resuspension of sediment in navigation pool 9 of the upper Mississippi River. Hydrobiologia, 126(3), 263-274.

Stuart, G.; Hollingsworth, A.; Thomsen, F.; Szylkarski, S.; Capati, B.; Khan, S.; Teo, L.; Tomlinson, R., and Kirkpatrick, S., 2009. Gold
Coast Seaway SmartRelease Decision Support System-Optimising recycled water release in a sub tropical estuarine environment. Water Science and Technology, 60, 2077-2084.

Stumpf, R.P. and Haines, J.W., 1998. Variations in tidal level in the Gulf of Mexico and implications for tidal wetlands. Estuarine, Coastal and Shelf Science, 46(2), 165-73.

Teasdale, P.R.; Welsh, D.T.; Dunn, R.J.K., and Robertson, D., 2009. Investigating Nutrient Sources and Processes in the Saltwater Creek Catchment. Gold Coast, Australia: Griffith Centre for Coastal Management, Research Report, 114p.

Tomlinson, R.; Robertson, A.; Drapper, D.; Teasdale, P.; Brooks, A.; Jordan, M.; Smith, M.; Moran, C., and Kirkpatrick, S., 2005 Mudgeeraba and Worongary Creek Catchment Management Study. Gold Coast, Australia: Griffith Centre for Coastal Management, Research Report, 362p.

Tomlinson, R.; Teasdale, P.; Connolly, R.; Lemckert, C.; Robertson, A.; Preston, K.; O'Halloran, K.; Webster, T.; Burns, P.; Cheung, L., and Hlinovsky, P., 2006. Saltwater Creek Environmental Inventory: Scoping Study Report and Recommendations. Gold Coast, Australia: Griffith Centre for Coastal Management, Research Report, $306 \mathrm{p}$.

Tomlinson, R.B., 1990. Flow and mass transport offshore from tidal inlets. In: Proceedings of the International Conference of Physical Modelling Transport and Dispersion (Boston, Massachusetts Institute of Technology).

Valdes, D.S. and Real, E., 1998. Variations and relationships of salinity, nutrients and suspended solids in Chelem coastal lagoon at Yucatan, Mexico. Indian Journal of Marine Sciences, 27, 149156

van Rijn, L.C., 1993. Principles of Sediment Transport in Rivers, Estuaries and Coastal Seas. Amsterdam: Aqua Publications, 650p.

Warnken, J.; Dunn, R.J.K., and Teasdale, P.R., 2004. Investigation of recreational boats as a source of copper at anchorage sites using time-integrated diffusive gradients in thin film and sediment measurements. Marine Pollution Bulletin, 49, 833-843. 